\title{
Anne-Baba İlgisinin Çocukların Okul Başarısı Üzerindeki Etkisi
}

\author{
Turhan Şengönül a,b
}

\section{Özet}

Bu makalenin amacı, anne-babanın eğitime ilgisi ile çocukların akademik başarısı arasındaki ilişki üzerine yapılmış araştırma literatürünü incelemektir. Araştırmacılar, anne-baba ilgisinin hem anaokulu, ilkokul, ortaokul hem lise öğrencilerinin akademik performansını etkilediğini ileri sürmektedir. Annebaba ilgisi, evde çocukları sosyalleştirme ve yetiştirme süreci ya da disiplin, anne-babaların çocuklarının eğitimi ve akademik başarısı için istekleri ve beklentileri, okulla iletişim, okul hakkında tartışmalar ve okul etkinliklerine katılım gibi çeşitli faktörler bakımından tanımlanmaktadır. Anne-babalar, çocuklarının daha iyi akademik performansını sağlamak amacıyla çocukları ile okul etkinliklerini tartışmakta, onların ev ödevini izlemekte, kontrol etmekte ve yardım etmekte, öğretmenlerle iletişim kurmakta, okul işlerine, etkinliklerine ve anne-baba-öğretmen toplantılarına katılmaktadır. Onlar çocuklarının daha çok eğitimsel kazanıma ve daha yüksek akademik başarıya sahip olmalarını beklemekte ve istemektedir. Anne-babaların bu eğitimsel beklentileri ve istekleri, çocukların akademik başarısı ile olumlu biçimde ilişkili olmaktadır.

\author{
Anahtar Kelimeler \\ Çocukları Sosyalleştirme \\ Anne-Baba İlgisi \\ Anne-Baba Beklentisi \\ Okul Başarısı
}

Makale Hakkında

Geliş Tarihi: 04.04.2019

Kabul Tarihi: 20.11.2019

Doi: 10.18026/cbayarsos.549463

\section{Influence of Parental Involvement on School Achievement of Children}

\begin{abstract}
The aim of this article is to examine the related research literature conducted on the relationship between parental involvement in education and children's academic achievement. Researchers have suggested that parental involvement influences the academic performance of students at kindergarten, primary school, secondary school as well as high school. Parental involvement is defined in terms of various factors such as discipline or the process of socializing and parenting children in the household, parental aspirations and expectations for children's education and academic achievement, communication, discussions about school, and participation in school activities. Parents discuss school activities with children, monitor, check and help with their homework, communicate with teachers, attend school functions and parent-teacher conferences in order to ensure better academic performance of their children. They expect and aspire for their children to have higher rates of educational attainment and higher academic achievement. These educational expectations and aspirations of parents are positively associated with academic achievement of children.
\end{abstract}

Keywords

Socializing Children

Parental Involvement

Parental Expectation

School Achievement

About Article

Received: 04.04.2019

Accepted: 20.11.2019

Doi: 10.18026/cbayarsos.549463 


\section{Giriş}

Eğitim, günümüzde toplumların gelişmesi için gerekli kurumlardan biri olarak kabul edilmektedir. Aile ve eğitim kurumları, bireylere belirli bilgileri, değerleri, davranışları öğrettiğinde bireylerin toplumda beklenen ve istenen yönde davranışlar gösterme olasıllğ̆1 artmaktadır. Bütün toplumlar eğitimi önemsemekte ve eğitimli birey sayısını arttırmaya çalışmaktadır. Okulların ve öğretmenlerin niteliği yanında anne-babaların çocuklarının eğitimiyle ilgilenme derecesi, çocukların akademik başarısını olumlu bir biçimde etkilemektedir. Teorisyenler ve araştırmacılar, anne-babaların eğitim yönünde sahip oldukları tutumları ve çocuklarının eğitimi için katıldıkları etkinlikleri vurgulamakta, eğitim ve okul yönündeki olumlu tutumların çocukların artan akademik performansı ile ilişkili olduğunu ileri sürmektedirler (Rimm-Kaufman, Pianta, Cox ve Bradley, 2003). Araştırmalar anne-babaların çocuklarının akademik etkinliklerine ilgi derecesi ile çocuklarını akademik başarı düzeyi arasındaki ilişkiyi incelemektedir. Aileler onların eğitimi ile ilgilendiğinde çocuklar büyük olasılıkla yüksek akademik başarı düzeylerine ve gelişmiş davranışa sahip olabilmektedir (Bryan, 2005). Eğitim kurumları kadar aile de bireyleri toplumun değerleri yönünde sosyalleştirmede ve eğitmede önemli bir rol oynamaktadır. Öğrenme evde ailedeki etkileşim yoluyla başlamaktadır. Çevresel ve ekonomik faktörlerle birlikte anne-babaların çocukların eğitimiyle ilgilenmesi, çocukların biliş, dil ve sosyal beceriler gibi alanlarda gelişimini etkilemektedir. Bu alanda araştırmalar okula girmeden önceki yıllarda aile etkileşiminin ve ilgisinin önemini göstermektedir (Wynn, 2002). Çocuklarının eğitimi boyunca anne-babaların onların eğitimine gösterdikleri ilgiyle ortaya çıkan sürekli çabaları akademik başarıyı geliştirmektedir (Driessen, Smith ve Sleegers, 2005). Anne-babalar çocuklarını sosyalleştirmek ve eğitmek için ne kadar çok ilgilenir ise çocuklar toplumda yaratıı ve sorumlu bireyler olabilmekte ve okulda başarı gösterebilmektedir. Anne-babalar onların daha iyi bir akademik performans elde etmesi ve okul başarısını arttırması için çocuklarını parasal olarak ve duygusal olarak desteklemekte, motive etmekte onlar için eğitimsel materyaller sağlamaktadır. Anne-babaların çocuklarının eğitimiyle ilgilenmesi önemli olmakla birlikte anne-baba ilgisinin boyutları çeşitli biçimlerde vurgulanmaktadır. Çocuklarındaki akademik performansı ilerletmek için anne-babalar, evde çocukları ile belirli bir etkileşime girmekte ve çocuklarının eğitimiyle ilişkili olarak okulla bağlantılarını sürdürmektedir. Anne-baba ilgisi, anne-babaların evde ve okulda çocuğunun eğitimiyle meşgul olduğu etkinlikler ve anne-babaların çocuğunun eğitimi, okulu ve öğretmeni yönünde sahip olduğu olumlu tutumlar olmak üzere birçok yolla tanımlanmakta ve ölçülmektedir (Kohl, Lengua ve McMahon, 2000). Anne-babalar, okul saatleri dışında çocuklarına eğitim hakkındaki tutumlarını iletmekte ve bu tutumlar, çocukların sınıftaki davranışlarına ve öğretmenlerin çocuklarla ve anne-babalarla ilişkilerine yansımaktadır (Kellaghan, Sloane, Alvarez ve Bloom, 1993). Anne-baba ilgisi, çocuklarına okumada yardım etme, onları ev ödevlerini bağımsız olarak yapması için teşvik etme, evin içinde ve ev dışında onların etkinliklerini izleme ve farklı konularda öğrenmelerini geliştirmek için özel ders alma hizmetleri sağlama gibi etkinlikleri içermektedir (Topor, Keane, Shelton ve Calkins, 2010). Feurstein (2000) anne-baba ilgisini, anne-babaların veli toplantılarına katılarak çocuklar ile okul etkinliklerini tartışma gibi birçok davranışı kapsayan bir etkinlik olarak belirtirken, Holloway, Yamamoto, Suzuki ve Mindnich (2008) hem ev ödevini izleme, kontrol etme gibi evdeki davranışları hem de okul organizasyonlarına katılma ve öğretmenlerle iletişim kurma gibi çocukların eğitimiyle ilgili etkinlikleri gerçekleştirme olarak tanımlamaktadır. McNeal Jr. (2014) anne-baba ilgisine ilişkin geliştirdiği modelde 
anne-babalar ile çocuklar arasındaki konuşmalar ve tartışmalar, anne-babaların veli toplantılarına katılımı, okul etkinlikleriyle doğrudan meşgul olmaları, çocukların akademik ilerlemesini izlemeleri biçiminde dört öğeyi belirlemekte ve anne-babalar ile çocuklar arasındaki konuşmaları ve tartışmaları en önemli öğe olarak görmektedir. Anne-baba ilgisi, anne-babaların çocukları ile tartışması (Halle, Kurtz-Costes ve Mahoney, 1997), annebabaların çocuklarının akademik başarısı için beklentileri (Sanders ve Sheldon, 2009), annebabaların okul etkinliklerine katılımı (Barnard, 2004) ve çocukları sosyalleştirmenin ve yetiştirmenin farklı biçimleri (Dornbush, Ritter, Leiderman, Roberts ve Fraleigh, 1987; Steinberg, Lamborn, Dornbusch ve Darling, 1992) gibi anne-babaların farklı uygulamalarını ve davranışlarını içermektedir. Anne-baba ilgisi, anne-babaların (a) çocuklarının okuldaki etkinlikleriyle, (b) çocuklarının evdeki eğitim etkinlikleriyle, (c) çocuklarının doğrudan akademik etkinlikleriyle ve (d) çocuklarının dolaylı olarak akademik etkinlikleriyle ilgilenmesi olarak dört geniş alanda sınıflandırılabilmektedir. Anne-babaların eğitimsiz ya da daha eğitimli olma durumu, iş ya da mesleki statüsü, iş yaşamı, sosyal çevre gibi sosyoekonomik statü değişkenine bağlı olarak çocuklarının eğitimiyle ilgilenme derecesi değişebilmektedir. Anne-babalar ilk yaştan itibaren çocuklarıyla ilgilendiğinde, belirli bir kişilik oluşturmak için onlara belirli değerleri, iyi tutumları ve davranışları kazandırabilmekte, onlara yol gösterebilmekte ve onların yaşamını biçimlendirebilmektedir. Çocuklar sosyalleştirilme süreçlerinde anne-babaların benimsedikleri, içselleştirdikleri değerleri ve gösterdikleri davranışları model alabilmektedir. Sosyoekonomik statü, sosyal sınıf, aile boyutu gibi sosyal köken faktörleri göz önüne alındığında bile anne-babaları tarafından çocuklarının eğitimine gösterilen ilgi, çocuklarının akademik başarısını olumlu bir biçimde etkilemektedir (Deslorges ve Abouchar, 2003).

Günümüzde eğitimin ve eğitim alanındaki başarının bir değer olarak kabul edilmesi eğilimi, yazarı bu literatür araştırmasını yapmaya motive etmiştir. Bu literatür araştırması, eğitim dünyasına ve akademik alana katkı sağlayabilmek ve yararlı olabilmek amacıyla yapılmıştır. Aileler, okullar, öğretmenler, okul yöneticileri, milli eğitim bakanlığı, üniversiteler, eğitimle ilgili kuruluşlar, uzmanlar ve tüm toplum, eğitimi ve eğitim alanındaki başarıyı önemli ve değerli olarak görmekte ve öğrencilerin okulda akademik olarak daha başarılı olmasını istemektedir. Aileler ve okullar öğrencilerin akademik başarısını artırmayı amaçlamakta ve bu amaca ulaşabilmek için çabalarını yoğunlaştırmaktadır. Anne-babaların çocuklarının eğitimine gösterdikleri ilginin çocuklarının akademik başarılarını nasıl etkilediği konusuna odaklanan bu çalışma, ailelere, öğretmenlere, okul yöneticilerine yararlı olacak, aydınlatıcı ve yol gösterici bilgileri yansıtan araştırma bulgularına işaret etmektedir

\section{Araştırmanın Amacı}

$\mathrm{Bu}$ çalışmanın amacı, anne-babaların eğitim alanında çocuklarına gösterdikleri ilgi ile çocuklarının akademik başarısı arasındaki ilişki üzerine yapılmış araştırma literatürünü incelemektir. Bu araştırma, anne-babaların çocukları için eğitim alanında gösterdikleri ilginin nasıl tanımlandığını ve tartışıldığını, anne-baba ilgisinin okul öncesi ana sınıfı, ilkokul, ortaokul ve lise düzeylerinde öğrencilerin akademik başarıları ile ilişkilerini ele almayı amaçlamaktadır. 


\section{Araştırmanın Yöntemi}

$\mathrm{Bu}$ çalışma, anne-babaların eğitim alanında çocuklarına gösterdiği ilginin yönlerini ve boyutlarını tanıtmakta ve anne-baba ilgisinin öğrencilerin akademik başarısını nasıl etkilediği üzerine odaklanmaktadır. Yazar, anne-babaların çocuklarına eğitim alanında okul öncesi, ilkokul, ortaokul ve lise dönemlerinde gösterdikleri ilgiyi ve bu ilginin yönleri ve boyutlarının neler olduğunu betimlemeye ve açıklamaya çalışmaktadır. Bu çalışma annebabaların eğitim alanında çocuklarına ilgisi ile öğrencilerin akademik başarısı arasındaki anlamlı ve tutarlı ilişkileri bulan araştırmalara ve bu araştırmaların bulgularına odaklanmaktadır. Çalışmada anne-baba ilgisi ve çocukların akademik başarısı arasındaki ilişkiye aracılık eden değişkenleri açıklamada teorik çerçeve ya da kavramlar belirlenmekte ve tanımlanmaktadır. Anne-babaların eğitime ilişkin değerleri, inançları, tutumları, çocuklarını sosyalleştirme ve yetiştirme biçimi, anne-babaların çocuklarının eğitimi ve akademik başarısı için istekleri, beklentileri bu çalışmada teorik çerçeve ya da kavramlar olarak yer almıştır. Bu çalışmada yazar, anne-baba ilgisi ile öğrencilerin akademik başarısı arasındaki ilişkiyi araştırmak için anne-babaların eğitim alanında çocuklarına gösterdiği ilginin okul öncesi, ilkokul, ortaokul ve lise dönemlerinde öğrencilerin akademik başarıları üzerindeki etkisi üzerine yapılan araştırmaları, yeniden incelemeleri, meta analizleri, raporları ve kitapları incelemiştir.

\section{Anne-Babaların Çocuklarının Eğitimine İlgisini Tanımlama ve Kavramlaştırma}

Teorisyenler ve araştırmacılar, anne-babaların eğitim alanında çocuklarına gösterdiği ilginin yönlerini ve boyutlarını tartısmaktadır. Anne-baba ilgisi, ailede anne-babaların çocuklarına uyguladıkları disiplin, anne-babaların çocuklarının eğitimini sürdürmesi ve akademik başarısı için istekleri ve beklentileri, çocuklarıyla okul hakkındaki konuşmaları, tartışmaları, onların okulla ilişkili etkinliklere katılımı gibi öğelerle tanımlanmaktadır (Singh, Bickley, Keith, Keith, Trivette ve Anderson, 1995). Anne-baba ilgisi, anne-babaların sosyalleştirme ve çocuk yetiştirme süreçlerinde çocuklarına destekleyici ve yardım eden tutum ve davranışlar göstermesi ve onların eğitimsel süreçlerine ve deneyimlerine katılması olarak gerçekleşmektedir. Bir yandan çocuklarının eğitim alanında yüksek düzeylerde başarılı olabilmesi için anne-babaların yüksek beklentilerini sürdürmesi, çocuklarıyla daha çok iletişim kurmaları, okul etkinlikleri konusunda görüş alışverişi yapmaları, öğretmenlerine vermeden önce çocuklarının ev ödevlerini kontrol etmeleri, diğer yandan anne-babaların okul organizasyonlarına ve etkinliklerine ilgisi ve katılımı gibi öğeler, anne-baba ilgisinin boyutları olarak belirlenmektedir (Jeynes, 2007). Shute, Hansen, Underwood ve Razzouk (2011) anne-baba ilgisini, evdeki etkinlikler ve okul yönündeki etkinlikler olarak iki ana kategoride gruplamaktadır. Evdeki etkinliklerle anne-babalar hem çocuklarına belirli değerleri, tutumları, davranışları ve standartları iletmekte ve göstermekte hem de çocuklarına onların eğitimi ve akademik başarısı için isteklerini ve beklentilerini iletmektedir. Çocuklarının okuluyla ilgilenme temelinde anne-babalar, bir yandan çocuklarıyla okul etkinlikleri, programları ve okul planları hakkında konuşmakta ve tartışmakta, diğer yandan okuma etkinliklerine model olarak ve destekleyerek evde çocuklarına okuma yapmakta, onların ev ödevlerini kontrol etmekte, onların evdeki belirli kurallara uymasını sağlamakta ve onları gözetlemekte ve denetlemektedir. Anne-babalar öğretmenlerle iletişim kurmakta, okul organizasyonlarına katılmakta, okulla ilişkili çalışmalarda ve etkinliklerde gönüllü olmaktadır. 


\section{Anne-Baba İlgisinin Öğrencilerin Akademik Başarısı Üzerindeki Etkisi ile İlişkili Araştırma Bulguları ve Tartışmalar:}

Anne-babalar çocuklarının eğitimi alanında dört yönde ya da boyutta ilgisini göstermektedir. Onlar, (a) çocuklarını sosyalleştirmekte ve yetiştirmekte, (b) evde çocuklarının eğitimiyle ilgilenmekte, (c) çocuklarının okuluyla ilgilenmekte ve (d) çocuklarının eğitimi ve akademik başarısı için beklentilerini ve isteklerini sürdürmektedir. Araştırmalar, anne-babaların çocuklarına gösterdikleri bu ilginin yön ve boyutlarının öğrencilerin akademik başarısı ile ilişkili olduğunu bulmaktadır.

\section{Çocukları Sosyalleştirme ve Yetiştirme Biçimi İle Çocukların Akademik Başarısı Arasındaki İlişki}

Araştırmacılar anne-babaların çocuklarını sosyalleştirme ve yetiştirme biçimi ile çocukların akademik başarısı arasındaki ilişkilere işaret etmişlerdir. Baumrind (1978) çocukları sosyalleştirmede ve yetiştirmede demokratik, otoriteryan ve aşırı serbestlik sağlayan biçim olarak başlıca üç yaklaşımı belirlemiştir. Baumrind (1991) çocukları sosyalleştirmede ve yetiştirmede istekler ve duyarlılık boyutlarını vurgulayarak, demokratik tutum ve davranış sergileyen anne-babaların çocuklarına duyarlı davrandıklarını ve onlara belirli isteklerini ilettiklerini ileri sürmüştür. Araştırmada bu anne-babaların çocuklarına daha çok sevgi gösterdikleri ve onları araştırmaya, keşif yapmaya teşvik ettikleri ve ilgi duydukları alanlarda meşgul olmasını sağlamaya çalıştıkları gözlenmiştir. Baumrind, otoriteryan annebabaların ise belirli isteklerini çocuklarına iletmekle birlikte onlara duyarlılık göstermediklerini, çocuklarıyla daha az ilgilendiklerini ve onlarla açık iletişimi yeterli düzeyde kurmadıklarını belirtmiştir. Çocuklarına aşırı yüz veren anne-babaların da çocuklarına duyarlılık göstermekle birlikte belirli isteklerini onlara iletmedikleri ya da çocuklarından istekleri olmadığı görülmüştür. Araştırmada çocuklarına duyarlılık göstermeyen ve onlara isteklerini iletmeyen ya da onlardan istekleri olmayan anne-babaların çocuklarına aşırı serbestlik sağlayarak onları ihmal ettikleri belirlenmiştir (Dornbush, ve diğerleri, 1987).

Araştırmacılar, çocukları sosyalleştirmede ve yetiştirmede demokratik biçim ve uygulamalar ile öğrencilerin akademik başarısı arasında olumlu bir ilişki olduğunu bulmuşlardır (Dornbush ve diğerleri, 1987; Lamborn, Mounts, Steinberg ve Dornbusch, 1991). Erdoğdu (2007) annelerin olumlu tutumlarının çocukların akademik başarısı ile daha çok ilişkili olduğunu ve anne-babalar çocuklarına demokratik davranışlar sergilediklerinde, onların gelişimi ile ilgilendiklerinde ve onların okul çalışmalarına destek olduklarında çocuklarının akademik başarılarının arttı̆̆ını ileri sürmüştür. Diğer yandan, sosyalleştirme süreçlerinde anne-babaların çocuklarına aşırı serbestlik sağlaması ile öğrencilerin okul başarısı arasında olumsuz bir ilişkinin var olduğuna işaret edilmiştir (Baumrind, 1978; Dornbush ve diğerleri, 1987; Maccoby, 2000). Baumrind (1967) bir araştırmasında çocuklarına aşırı serbestlik sağlayan ailelerden gelen anaokulu çocuklarının kendine güvenlerinin daha az olduğunu ve yeteneklerinin daha düşük olduğunu bulurken, demokratik tutumlar ve davranışlar sergileyen ailelerden gelen anaokulu çocuklarının daha aktif, sosyal yanlı ve başarı yönelimli olduklarına işaret etmiştir. Baumrind (1991) ergenlikte bu ilişkiyi tekrar incelemiş ve daha önceki araştırma bulgularında vurgulandığı gibi çocukları sosyalleştirmede ve yetiştirmede demokratik biçim ve uygulamaların çocukların okul başarısını olumlu bir biçimde etkilediği sonucuna ulaşmıştır. Dornbush ve diğerleri (1987) Baumrind'in çocukları sosyalleştirme ve 
yetiştirme tipolojisini geliştirerek ve test ederek, iki karşıt yaklaşım olarak anne-babaların çocuklarına otoriteryan tutum ve davranışları ile aşırı serbestlik sağlayan tutum ve davranışların erkek ve kız ergen öğrencilerin okul başarısı ile olumsuz biçimde ilişkili olduğunu bulmuşlardır.

Araştırmacılar anne-baba sevgisi ile öğrencilerin okul başarısı arasında güçlü bir ilişkinin var olduğuna işaret etmişlerdir. Şentürk (2012) ailedeki sevgi, güven ve kabul edilme gibi temel psikolojik gereksinimlerin karşılanmasının insan gelişiminin temel koşulu olduğunu, annebabaların sevgi ve ilgisinden yoksun kalan çocukların yalnızlık duygusunu daha çok hissettiklerini ve çalışma, araştırma ve başarı elde etme çabasını daha az gösterdiklerini ileri sürmüştür. Bir araştırmada, Deslandes, Royer, Turcotte ve Bertrand (1997) anne-babaların demokratik desteği ile hem erkeklerin hem kızların okul başarısı arasında anlamlı ve tutarlı bir ilişki olduğunu bulmuşlardır. Yılmaz (2000) lise birinci sınıf öğrencileri ile ilişkili araştırmasında anne-babaların çocuklarına sağladıkları psikolojik özerkliğin öğrencilerin akademik başarısını etkilediğini vurgulamıştır. Psikolojik özerklik erkek öğrencilerin akademik başarısı ile ilişkili bulunurken, psikolojik özerklik ve kabul/ilgi boyutu kız öğrencilerin akademik başarısı ile ilişkili olmuştur. Arcan (2006) ise anne-babaların, çocuklarına gösterdiği demokratik tutumun ve davranışların öğrencilerin başarı puanlarını olumlu biçimde etkilediğine işaret etmiştir. Araştırmada çocukları sosyalleştirmede ve yetiştirmede demokratik biçiminin boyutları olarak anne-babaların çocuklara sağladığı psikolojik özerklik hem erkek öğrencilerin hem de kız öğrencilerin başarı puanları ile ilişkili olurken, çocukları kabul etme/ilgi gösterme kız öğrencilerin başarı puanları ile ilişkili görünmüştür. Bir meta çözümleme yapan araştırma, destekleyici, yardımcı ve uygun disiplin olarak nitelenen sosyalleştirme süreçlerindeki demokratik uygulamalar ile ortaokul öğrencilerinin akademik başarısı arasındaki güçlü olumlu ilişkiyi vurgulamıştır (Jeynes, 2007). Araştırmalarında, Steinberg ve diğerleri (1992) çocukları sosyalleştirmede ve yetiştirmede demokratik biçim ve uygulamaların ergenlerin okul meşguliyetine ve genel puan ortalaması olarak daha iyi bir okul performansına yol açtığını bulmuşlardır. Benzer biçimde, Nyarko (2011) hem annelerin hem babaların çocukları sosyalleştirme ve yetiştirme süreçlerindeki demokratik tutum ve davranışlarının ortaokul öğrencilerinin akademik başarısıyla olumlu biçimde ilişkili olduğunu belirtmiştir. Paulson (1994) çalışmasında çocuklarını sosyalleştirmek ve yetiştirmek için anne-babaların gösterdikleri duyarlılığın ve ilettikleri isteklerin erken ergenlerin başarısı üzerindeki etkisini araştırmıştır. Hem annelerin hem babaların duyarlılığı ve istekleri, öğrencilerin okul başarısını olumlu bir biçimde etkilemiştir. Deslandes ve diğerleri (1997) araştırmalarında anne-babalarının sıkı, sıcak ve demokratik biçimde davrandıklarını söyleyen ergenlerin akranlarına göre ortaokulda daha iyi performans gösterdiklerini bulmuşlardır. Bu sonuç, Dornbush ve diğerlerinin (1987) ve Kim'in (2002) yürüttükleri araştırmalarda elde ettikleri bulgularla benzerlik göstermiştir. Diğer bir araştırmada Marchant, Paulson ve Rothlisberg (2001) sosyalleştirme ve yetiştirme süreçlerinde anne-babaların çocukları için duyarlılığı ve istekleri, çocuklarının eğitimi yönünde gösterdikleri ilgisi, anne-babaların eğitime ilişkin değerleri ve okul organizasyonlarına katılımı, çocuklarına öğretme yönünde gösterdikleri duyarlılık ve istekleri gibi faktörler ile çocukların okul başarısı arasında anlamlı bir ilişki olduğunu bulmuşlardır. Bu bulgular, destekleyici aile çevresi ile ergenliğin erken döneminde akademik başarı arasındaki ilişkiyi doğrulamıştır. Anne-babaların çocuklarını sosyalleştirme ve yetiştirme süreçlerinde onlara okul başarısını yükseltmesi için kullandıkları akademik 
stratejileri öğrettiklerine işaret eden Aunola, Stattin ve Nurmi (2000) demokratik tutum ve davranışlar sergileyen ailelerden gelen ergenlerin başarı stratejilerini uygularken, çocuklarını ihmal eden ailelerden gelen ergenlerin uyumsuz ve görevden kaçma eğilimleri gösterdiklerini belirtmişlerdir. Çocukların izledikleri başarı stratejilerinin onların akademik performansıyla anlamlı biçimde ilişkili olduğu görülmüştür. Sosyalleştirme ve yetiştirme biçiminin çocukların sosyalleştirmesi ve yetiştirilmesi süreçlerindeki uygulamaları yönettiğini ve çocukların okul başarısı ile ilişkili olduğunu vurgulayan araştırmalar, çocuklarını sosyalleştirme ve yetiştirme süreçlerinde demokratik tutum ve davranışlar sergileyen anne-babaların çocuklarıyla ilgilendiklerini, onları izlediklerini, kontrol ettiklerini, okulda verilen ev ödevinde onlara yardım ettiklerini göstermiştir. Anne-babaların bu tür sosyalleştirme uygulamaları ile ergenlerin okul başarısı arasında anlamlı bir ilişkinin olduğu doğrulanmıştır (Steinberg ve diğerleri, 1992). Benzer biçimde, Akın (2009) araştırmasında çocuklarına demokratik, hoşgörülü ve güven verici tutum ve davranışlar gösteren annebabaların öğrencilerin akademik başarılarını olumlu biçimde etkilediği sonucuna ulaşmıştır. Satır (1996) ise araştırmasında çocuklarına yakın ilgi gösteren, çalışmayı planlayan ve çalışma ortamını düzenleyen ve çocuklarının akademik başarısını öven, destekleyen ve çalışma yoluyla akademik başarısızlığın üstesinden gelebileceğini çocuklarına telkin eden anne-babaların çocuklarının akademik başarılarının yüksek olduğunu bulmuştur.

\section{Anne-Babaların Evde Çocuklarının Eğitimiyle İlgilenmesi İle Çocukların Akademik Başarısı Arasındaki İlişki}

Araştırmalar, anne-babaların evde çocuklarının eğitimiyle ilgilenmesi yoluyla çocuklarının akademik başarısını etkilediklerini ileri sürmüşlerdir. Anne-babaların çocukları ile iletişim kurması, çocukları için evde bir öğrenme ortamı yaratması, okulda çocuklarına verilen ev ödevini izlemesi, kontrol etmesi ve yardım etmesi gibi stratejiler, evde çocukların eğitimiyle ilgilenmenin göstergeleri olarak belirlenmiştir (Jaiswal ve Choudhuri, 2017). Şad (2012) annebabaların evde çocuklarıyla okulla ilgili konuşmaları, çocuklarının ev ödevine yardım etmesi, okuldaki etkinliklere ve toplantılara gönüllü olarak katılımı, öğretmenlerle görüşme gibi anne-baba ilgisinin öğrencilerin akademik başarısını olumlu yönde etkilediğini bulmuştur. Graves ve Wright (2011) ise araştırmalarında anne-babaların çocuklarının eğitimiyle ilgilenerek evde çocuklarına okuryazarlığı öğretmeyi teşvik eden ortam sağlaması, okumada çocuklarına model olması ve onların okumasını desteklemesi ile çocukların akademik başarısı arasında olumlu bir ilişki olduğunu bulmuşlardır. Benzer biçimde, Çelenk (2003) anne-babalar çocuklarında ilk okuma yazma ve okuduğunu anlama becerilerini geliştirmek için evde onlara yardım ettiklerinde, çocukların okulda daha başarılı oldukları sonucuna ulaşmıştır. Evde çocuklarıyla derslerle ilgili okuma-yazma etkinliklerini ve çalışmalarını sürdüren anne-babaların çocuklarının okuryazarlık gelişimini olumlu bir biçimde etkiledikleri görülmüştür. Evde çocuklarına derslerle ilgili okuma-yazma etkinliklerini ve çalışmalarını nasıl sağlayacaklarına ilişkin bir programa katılması yoluyla öğrendikleri bilgileri ve becerileri uygulayan anne-babalar, çocuklarının daha yüksek düzeyde okuryazarlık başarısı elde etmesinde önemli bir rol oynamışlardır. Evde okuryazarlık derslerinin gerektirdiği etkinlikleri ve çalışmaları yapan anne-babaların çocukları, etkinlikleri ve çalışmaları daha az yapan ya da hiç yapmayan anne-babaların çocuklarına göre daha yüksek düzeyde okuryazarlık başarısı kazanmışlardır (Crosby, Rsinski, Padak ve Yıldırım, 2015). Bununla birlikte, Keçeli-Kayısılı (2008) anne-babaların "eğitimin, öğrenmenin okulda ve öğretmenin sorumluluğunda gerçekleşmesi gerektiği" gibi 
bir anlayışa sahip olduklarında, evde çocuklarının eğitimiyle hiç ilgilenmediklerini ya da daha az ilgilendiklerini ileri sürmüştür. Araştırmada anne-babalar çocukları için evde öğrenme etkinlikleriyle meşgul olduklarında, okul öncesi ana sınıfı öğrencilerinin akademik başarılarının arttığı bildirilmiştir. Anne-babalar çocuklarıyla ilgilenerek, çocuklarını bilişsel olarak teşvik eden etkinliklere kattıklarında, onlara öyküler okuduklarında, harfleri ve sayıları öğrettiklerinde, onlar için problem çözme etkinlikleri yaptıklarında, onlarla şarkılar söylediklerinde ve oyunlar oynadıklarında, çocukların okuryazarlık becerilerinin geliştiği (Manolitsis, Georgiou ve Tziraki, 2013) ve okuma başarısının arttığı gözlenmiştir (Wen, Bulotsky-Shearer, Hahs-Vaughn ve Korfmacher, 2012). Ülkemizde Anne Çocuk Eğitim Vakfı (AÇEV) tarafından yürütülen ve okul öncesi ana sınıfına devam edemeyen ve risk grubundaki öğrencilerin eğitim gereksinimlerini karşlamak, onların bilişsel, sosyal ve duygusal gelişimlerine katkı sağlamak ve akademik başarıları üzerindeki olumsuz etkileri azaltmak amacıyla Anne-Çocuk Eğitim Programı (AÇEP) hazırlanmıştır. Bu program, Erken Destek Araştırma Projesi verileri 1şığında Kağıtçıbaşı, Bekman ve Sunar tarafından geliştirilmiştir. 5-6 yaş arasında okul öncesi eğitim hizmeti almamış çocuklara ve annelerine uygulanan Anne-Çocuk Eğitim Programının (AÇEP) çocuklara okulda kullanacakları sözel ve sayısal becerileri etkili biçimde kazandırdığ1 ve onları okula hazırladığı görülmüştür (Keçeli-Kayısılı, 2008). Araştırmalar bu programa katılan anne-babaların çocuklarının zeka ve genel yetenek testlerinde daha yüksek puan aldıklarını, okulda daha başarılı olduklarını, eğitimlerine uzun süre devam ettiklerini, daha olumlu bir benlik kavramı geliştirdiklerini ve daha yüksek prestijli meslek edindiklerini göstermiştir (Bekman, 1998).

İlkokul öğrencileri üzerinde yaptıkları araştırmalarda Hemmerechts, Agirdag ve Kavadias (2017) anne-babaların evde çocuklarına okuma etkinlikleri ile ilkokul öğrencilerinin okuryazarlık performansı arasında anlamlı bir ilişki olduğunu bulmuşlardır. Evde çocuklarını okuma etkinlikleri ile meşgul eden anne-babalar okuldaki çocuklarının okuma başarısına katkı yapmışlardır. Benzer biçimde diğer bir araştırma, anne-babalar çocuklarını okul yaşamlarının başlangıcında okuması için eğittiklerinde, çocuklarına örnek biçimde okuduklarında ve öğrettiklerinde, ilkokul öğrencilerinin notlarının ve akademik performanslarının arttı̆̆ına işaret etmiştir. Anne-babaların çocuklarını okuması için eğitmesi ile çocuklarının dil performansı arasında olumlu bir ilişki gözlenmiştir (Kloosterman Notten, Tolsma ve Kraaykamp, 2011).

Ortaokul öğrencileri üzerine yaptığı araştırmada Zakaria (2013) anne-babaların çocuklarına gösterdikleri ilgiyi, anne-babaların (a) çocuklarıyla ilişkileri, etkileşimleri ve iletişimleri, (b) çocuklarını sosyalleştirmek ve eğitmek için başvurdukları uygulamalar, (c) boş zamanlarda çocuklarıyla birlikte yaptıkları etkinlikler ve yaşadıkları deneyimler, (d) çocuklarına açık olması ve onları kabul etmesi olarak dört biçimde belirlemiştir. Araştırmada anne-babaların çocuklarına bu tür ilgisi ile öğrencilerin okul başarısı arasında olumlu bir ilişkinin olduğu görülmüştür. Anne-babalar onlarla ilgilendiklerinde, öğrenciler ev ödevi etkinliklerini daha az zor ve daha çok zevkli olarak algılamışlardır (Zakaria, 2013). Katz, Kaplan ve Buzukashvily (2011) okulda verilen ev ödevlerini kabul etmesi için öğrencilere gerekli motivasyonu kazandırmada anne-babaların oynadıkları rolü araştırmak için teorik bir çerçeve olarak kendini-belirleme teorisini kullanmışlardır. Araştırmacılar anne-babaların çocuklarına okulda verilen ev ödevlerini yapmaları için yeterlilik duygusu, inançlar ve olumlu tutumlar kazandırması ve çocukların psikolojik gereksinimlerini karşılaması ve 
desteklemesi ile çocukların okulda verilen ev ödevlerini yapması için özerk motivasyona sahip olması arasında anlamlı ve tutarlı bir ilişki olduğunu bulmuşlardır. Cooper, Lindsay, Nye ve Greathouse (1998) tarafından yürütülen araştırmada anne-babaların çocuklarına okulda verilen ev ödevi yönündeki olumlu tutumlarının, ilkokul öğrencilerinin daha yüksek başarı puanları ve notları ile olumlu biçimde ilişkili olduğu görünmüştür. Diğer bir araştırmada Hill ve Craft (2003) anne-babalar, çocuklarıyla birlikte bilişsel olarak teşvik eden ev etkinlikleriyle meşgul olduklarında, ilkokul öğrencilerinin matematik başarı puanlarının anlamlı bir biçimde arttı̆̆ını bulmuşlardır. Ortaokul öğrencileri üzerine yaptıkları araştırmada Sui-Chu ve Willms (1996) anne-babaların okula katılımından çok, onlar evde okulla ilişkili etkinlikler hakkında çocukları ile konuştuklarında, tartıştıklarında, çocuklarının akademik başarısının arttığını vurgulamışlardır. Başka bir araştırmada annebabaların çocuklarını akademik biçimde kontrol etmesi ile öğrencilerinin iyice öğrenme amacı arasında olumlu bir ilişkinin var olduğu görülmüştür (Regner, Loose ve Dumas, 2009). Clark (1993) anne-babalar çocuklarının okul sonrası davranışlarını kontrol ettiklerinde, çocuklarının okulda daha yüksek notlar, puanlar aldıklarını belirtmiştir. Benzer biçimde, ortaokul öğrencileri üzerine yapılan diğer bir araştırmada anne-babalar okulda verilen ev ödevlerini yapması için çocukların kontrol ettiklerinde, öğrencilerin akademik performansının ve okul başarısının arttığı gözlenmiştir. Anne-babalar televizyon izleme gibi çocuklarının etkinliklerini kontrol ettiklerinde, çocuklarının okul başarısı yükselmiştir (Keith T., Keith P., Troutman ve Bickley, 1993). Tam ve Chan (2009) ise araştırmalarında annebabaların çocuklarına sosyalleştirme sürecinde belirli ilkeleri ve yapıyı vermesi ile çocuklarının hem kendi akademik performansına ve yeteneğine güvenmesi, inanması hem de ilkokul öğrencilerinin öğrenmeye yoğunlaşması arasında olumlu bir ilişki olduğu sonucuna ulaşmışlardır. Hayes (2012) anne-babaların çocuklarının eğitimine ve akademik başarısına değer vermesi ve pekiştirmesi biçimindeki ilgisi ile öğrencilerin lise boyunca matematik başarısı arasında anlamlı bir ilişkinin olduğuna işaret etmiştir. Ho (2010) annebabalar çocuklarıyla ilgilenerek bilim öğrenmeyi teşvik eden, pekiştiren, güçlendiren etkinlikleri organize ettiklerinde, öğrencilerin bilim performanslarının arttığını bulmuştur. Anne-babalar çocuklarını bilim ve bilimsel buluşlar hakkında kitaplar okumaya, televizyon programlarını izlemeye, bilim kurguları seyretmeye, okumaya ya da dinlemeye teşvik etme gibi tutumları ve davranışlarıyla çocuklarının bilim başarısını ve yeterliliğini ilerletmede etkili bir rol oynamışlardır. Altschul (2011) araştırmasında anne-babalar çocuklarıyla ilgilendiklerinde, onlarla eğitimsel konuları tartıştıklarında, okulla ilişkili etkinlikler, yakın ve uzun süreli okul planları ve diğer akademik konular hakkında çocuklarıyla karşılıklı konuştuklarında, öğrencilerin akademik başarılarının arttı̆̆ını bulmuştur. Benzer biçimde, McNeal (2014) araştırmasında anne-babalar çocukları ile eğitim konularında konuştuklarında, tartıştıklarında, öğrencilerin akademik başarılarının iyileştiğini ve okulu asma gibi problematik davranışlarının azaldığını bulmuştur. Anne-babalar çocukları ile daha çok iletişim kurduklarında, 8. sınıf öğrencilerinin akademik başarılarının arttığına ve okulu asma davranışlarının azaldığına işaret edilmiştir.

Araştırmacılar anne-babaların çocuklarının ev ödeviyle ilgilenmesi ile öğrencilerin akademik başarısı arasındaki ilişkiyi vurgulamışlardır. Tam ve Chan (2009) anne-babaların çocuklarının ev ödevine ilgi göstermesi ile çocukların akademik gelişimi arasında olumlu bir ilişkinin olduğunu bulmuşlardır. Çocuklarının ev ödevlerine yardım etmek için eğitilen anne-babalar, ev ödevlerine yardım ettiklerinde, öğrencilerin matematik ev ödevi hakkında 
olumlu tutumlar geliştirdikleri ve matematik başarısını arttırdıkları görülmüştür. Gonida ve Cortina (2014) özerkliği destekleme, kontrol, müdahale, bilişsel olarak onlarla meşgul olma gibi anne-babaların çocuklarının ev ödevleriyle farklı ilgilenme biçimlerinin öğrencilerin akademik başarısını etkileyip etkilemediğini incelemişlerdir. Araştırmacılar anne-babalar onların ev ödevlerine yardım etme sürecinde çocuklarının özerkliğini desteklediklerinde, öğrencilerin akademik başarısının arttı̆̆ını, çocuklarının ev ödevlerine müdahale ettiklerinde, onların akademik başarısının olumsuz biçimde etkilendiğini belirtmişlerdir. Moroni, Dumont, Trautwein, Niggli ve Baeriswyl (2015) anne-babaların çocuklarının ev ödevlerine ilgisini, çocuklar destekleyici olarak algıladıklarında, böyle bir ilginin öğrencilerin akademik başarısı ile olumlu biçimde ilişkili olduğunu belirlerken, çocuklar anne-babalarını okulda verilen ev ödevlerini yapma süreçlerinde zorla araya giren ve kontrol eden kişiler olarak algılandıklarında, anne-babaların bu tür bir ilgisinin ve yardımının öğrencilerin akademik başarısı ile olumsuz biçimde ilişkili olduğunu bulmuşlardır. 1987' den 2004'e kadar yayınlanan 14 araştırmayı inceleyen meta çözümleme çalışması, çocuklarının ev ödeviyle meşgul olan eğitimli anne-babaların (a) çocuklarına okulda verilen ev ödevlerini büyük oranda yaptırdıkları, (b) çocuklarının ev ödevlerine ilişkin olası problemlerini azalttıkları, (c) ilkokul çocuklarında mümkün olduğunca gelişen, iyileşen akademik performansa yol açtıkları sonucuna ulaşmıştır (Patall, Cooper ve Robinson, 2008). Vural (2004) ise ülkemizde çocuklarına okulda verilen ev ödevini yapma alışkanlığını kazandırırken bazı anne-babaların ev ödevlerini kendilerinin yaptıklarına işaret etmiştir. Araştırmada anne-babalar çocuklarını okullara gönderdikten sonra çocuklarının eğitimi ile ilgili görevlerini tamamladıklarını, çocuklarının öğretmenlerini az tanıdıklarını ya da hiç tanımadıklarını bildirmişlerdir. Böyle bir durumun ise çocuklarının akademik başarısını olumsuz biçimde etkilediği görülmüştür. Eğitim düzeyi düşük anne-babalar çocuklarına yeterli düzeyde yardım edemediklerini bildirirken, memurlar, öğretmenler ve öğretim üyeleri çocuklarının okul çalışmalarına daha çok yardım ettiklerini belirtmişlerdir.

\section{Anne-Babaların Çocuklarının Okuluyla İlgilenmesi İle Çocukların Akademik Başarısı Arasındaki İlişki}

Araştırmacılar anne-babaların çocuklarının okuluyla ilgilenmesi yoluyla öğrencilerin akademik başarısında önemli roller oynadıklarını ileri sürmüşlerdir. Aslanargun (2007) okulun veli olarak anne-babalar ile kurduğu iletişimin, öğrencilerin okuldaki olası sorunlarını çözmek için gerekli olduğunu ve anne-babaların okulda düzenlenen etkinliklere katılımının öğrencilerin olumsuz davranışlarını azalttığını ve okula güdülenmesini artırdığını bulmuştur. Bir yandan anne-babalar çocuklarına okul öncesi dönemde bilinçli tutum ve davranışlar sergilediklerinde, onlarla iletişim kurduklarında ve oyunlar oynadıklarında, diğer yandan okul, sorumlu veli olarak anne-babalara çocuklarının sosyal duygusal gelişim özellikleri ve akademik başarı düzeyleri konusunda bilgi verdiğinde, öğrencilerin akademik başarılarının arttı̆̆ı gözlenmiştir. Özdayı (2004) anne-babaların çocuklarının öğretmenleri ve okul yöneticileri ile iletişim kurarak ve işbirliği yaparak, ortak bir çabayla öğrencilerde istenmeyen davranışları azaltılabildiğini ileri sürmüştür. Alkan (2018) ise araştırmasında okulla, öğretmenlerle iletişim kuran ve işbirliği yapan annebabaların çocuklarının okuldaki tutumları ve davranışları hakkında bilgi edindikleri için çocuklarının akademik başarılarını destekleyen ve başarısızlıklarını engelleyen davranışlar geliştirebildiklerini bulmuştur. Anne-babalar, çocuklarının okuluna ilgi göstermediklerinde, okula devam durumu kontrol edilmeyen ve devamsızlıkları engellenmeyen öğrencilerin 
akademik başarılarının düştüğü gözlenmiştir. Balcı (1988) etkili okuldaki eğitimin, öğretmen, okul yöneticisi, veli ve diğer tüm ilgililerin koordineli ve etkili bir biçimde iletişim kurmaları ve işbirliği yapmaları yoluyla onların ortak çabalarının bir ürünü olduğunu vurgulamıştır. Veli olarak anne-babalar çocuklarının eğitimiyle ilgilenmek, onların okuldaki eğitimlerini sürdürmek, desteklemek ve akademik başarı elde etmesini sağlamak için önemli roller oynamışlardır. Epstein (2001) ise çocukların eğitimi için okul, aile ve eğitimle ilgili topluluklar arasındaki ilişki ve etkileşimlerin önemli olduğunu belirtmiştir. Anne-babalar okulda ve eğitimle ilgili topluluklarda öğretmenlerle, eğitim uzmanlarıyla, yöneticilerle ve diğer insanlarla iletişim kurduklarında ve eğitimle ilgili kişiler ve kuruluşlarla işbirliği yaptıklarında, ortaya çıkan verimli entelektüel görüşmeler ve tartşmalar, çocuklar için verilen eğitimin niteliğini arttırmaya katkı yapmıştır. Entelektüel görüşmeler ve tartışmalarla alınan kararların ve uygulamaların okul programlarını ve okul ortamını iyileştirdiği ve aileleri, çocuklarının eğitimi konusunda daha çok bilinçlendirdiği görülmüştür. Epstein, ailelerin öğrendikleri yeni bilgiler, beceriler ve yaklaşımlarla çocuklarının eğitiminde daha olumlu rol oynadıklarına işaret ederek, anne-babaların çocuklarını okula daha iyi hazırladıklarında, onların okuldaki eğitimini olumlu biçimde etkilediklerini ve öğretmenlerin sınıftaki eğitimsel çabalarını kolaylaştırdıklarını bulmuştur. Epstein, ailelerin okulda ve eğitimle ilgili topluluklarda öğretmenlerle, eğitim uzmanlarıyla, yöneticilerle ve diğer insanlarla ilişki kurması ve işbirliği yapması yoluyla öğrencilerin okul başarısını arttırmaya yardım ettiğini vurgulamıştır.

Araştırmalar, çocuklarının okuldaki etkinlikleriyle ilgilenen anne-babaların öğretmenlerle iletişim kurduklarını, çocuklarının okula devamını kontrol ettiklerini, onların okul etkinliklerini izlediklerini, dönemsel akademik ilerleme raporların incelediklerini bulmuşlardır (Catsambis ve Garland, 1997; Shumow, Lyutykh ve Schmidt, 2011). Sibley ve Dearing (2014) anne-babaların çocuklarının okuluyla ilgilenmesi temelinde gösterdikleri bu tür tutumların ve davranışların çocuklarının eğitimi bakımından çok gerekli olduğunu ve anne-babaların çocuklarının okuluna ilgisi ile çocukların akademik başarısı arasında olumlu bir ilişkinin var olduğunu belirtmişlerdir. Anne-babalar öğretmenlerle iletişim kurduklarında, ilişki ve etkileşimleri sürdürdüklerinde ve okul etkinliklerine katıldıklarında, çocukların akademik başarılarının arttığı gözlenmiştir. Benzer biçimde, Pena (2000) araştırmasında çocuklarının okuluyla ilgilendiklerinde, anne-babaların okul etkinliklerine katıldıklarını, veli toplantılarına gittiklerini, okul organizasyonlarına katıldıklarını ve okulda gönüllü çalıştıklarını bulmuştur. Çocuklarının okuluyla ilgilenen anne-babaların sınıfı ziyaret ettiklerine ve ders öğretmenleriyle iletişim kurduklarına işaret eden Pena, annebabaların çocuklarının okuluyla ilgilenmesiyle öğretmenlerin verimliliğinin arttı̆̆ını ve aile ile okul arasında daha iyi bir ilişkinin ve iletişimin kurulduğunu belirtmiştir. Anne-babaların çocuklarının okuluyla yeterli düzeyde ilgilendiklerinde, okul çevresini ve ders öğrenimini olumlu biçimde etkiledikleri ve çocukların akademik performansını yükselttikleri görülmüştür (Pena, 2000).

Araştırmacılar anne-babaların çocuklarının okuluna ilgisi ile ilkokul öğrencilerinin artan akademik başarısı arasında var olan olumlu ilişkiye dikkat çekmişlerdir (Dearing, Kreider, Simpkins ve Weiss, 2006). Topor ve diğerleri (2010) anne-babalar çocuklarının öğretmenleri, okulu ve ilkokul düzeyinde çocuk eğitimi yönünde olumlu tutumlar sergilediklerinde, çocuklarının akademik performanslarının arttı̆̆ını bulmuşlardır. Bu tür olumlu tutumlar 
gösteren anne-babalar öğrencilerin akademik ya da davranış problemleri olduğunda öğretmenler ile iletişime geçtiklerini bildirmişlerdir. Benzer biçimde Hill ve Taylor (2004) anne-babaların, çocuklarının eğitim gördüğü ilkokulda sınıfı daha çok ziyaret ettiklerini ve ders öğretmenleri ile daha çok iletişim kurduklarını vurgulamıştır. Araştırmacılar, böyle ziyaretlerin, iletişimlerin ve etkileşimlerin, anne-babaların çocuklarının eğitimlerini sürdürdüğü okul programı hakkındaki bilgilerini, evde anne-baba ile çocuk arasında karşılıklı anlamayı ve anne-baba ilgisinin etkililiğini arttırdığını bulmuşlardır. Ergenlerin Sağlığı ile ilgili Ulusal Boylamsal Araştırmadan veri kullanan Mo ve Singh (2008) ise annebabaların ortaokuldaki çocuklarının eğitimine gösterdikleri ilginin öğrencileri olumlu ve anlamlı biçimde etkilediğini ve onların okuldaki öğrenme çabalarını arttırdığını ileri sürmüşlerdir. Araştırmacılar, anne-babalar, çocuklarının okuluyla ilgilendiklerinde, öğrencilerin daha çok öğrenme çabası, daha çok okul meşguliyeti ve daha iyi performans gösterdiklerini bulmuşlardır. Ülkemizde yapılan araştırmalarda anne-babaların çocuklarının eğitimiyle ilgilenmesinin bir göstergesi olarak onlara sundukları özel dershanelerden yararlanma olanaklarının onların akademik başarısını etkilediği ve diğer öğrencilerle karşılaştırıldığında dershaneye giden öğrencilerin TEOG sınavlarında daha başarılı oldukları görülmüştür. Savaş, Taş ve Duru (2010) özel dershanelere gitme fırsatı sunulan öğrencilerin matematikte daha yüksek başarı puanları elde ettiklerini bulmuşlardır. Başka bir araştırmada İpek (2011) çocuklarının eğitimine ilgisi ve katılımı yüksek olan ve eğitime tutumu olumlu olan velilerin çocuklarının Seviye Belirleme Sınav (SBS) puanlarının yüksek olduğunu, Seviye Belirleme Sınav (SBS) puanları düşük olan öğrencilerin anne-babalarının ise çoğunlukla çocuklarının eğitime ilgisinin ve katılımının az olduğunu bulmuştur. Ortaokul öğrencileri üzerinde yürüttükleri araştırmada Çiftçi ve Bal (2015) anne-babaların çocuklarına evde ve onların okuluna gösterdikleri ilgi ve katılım düzeyleri arttıkça, öğrencilerin akademik başarı puanlarının yükseldiğini bulmuşlardır. Ortaokul öğrencileri ile ilgili bir meta çözümleme yapan araştırmada Hill ve Tyson (2009) anne-babaların çocuklarının okuluyla ilgilenmesi yönünde okulda gönüllü iş yapma ve okul organizasyonlarına katılma gibi etkinlikleri ile çocuklarının okul başarısı arasında anlamlı bir ilişki olduğuna işaret etmişlerdir. Deutcher ve Ibe (2004) anne-babaların okulda gönüllü olması ile öğrencilerin motivasyonel düzeyi arasında olumlu bir ilişkinin olduğunu bulmuşlardır. Araştırmacılar, öğretmenler ile iletişimi düzenli sürdüren anne-babaların çocuklarının okulda ve okul dışında ders konuları hakkında ekstra bilgi araştırmak için daha çok motive olduklarını vurgulamışlardır. Benzer biçimde, Tan ve Goldberg (2009) okul organizasyonlarına katılma, sınıfta yardım etme, sınıf öğretmenleri ile iletişim kurma, veli toplantılarına katılma gibi etkinliklerle anne-babaların çocuklarının okuluyla doğrudan ilgilenmesi ile onların okul başarısı, okul kazanımı ve okul zevki arasında olumlu ilişki olduğunu bulmuşlardır. Anne-babaların ilgilenerek, çocuklarına müdahale etmesi ile çocukların daha sonraki okul başarısı ya da yeteneği arasındaki ilişkiyi incelemek amacıyla yürüttükleri boylamsal bir araştırmada Miedel ve Reynolds (1999) anne-babaların çocuklarının ana sınıfındaki etkinliklerine daha çok katılmaları ile çocuklarının daha sonra 8. sınıfta dersleri akılda daha çok tutabilmeleri ve daha çok akademik başarı elde etmeleri arasında anlamlı bir ilişkinin olduğunu bulmuşlardır.

Araştırmalar anne-babaların ilkokul çağındaki çocuklarının okul etkinlikleriyle daha çok meşgul olduklarını göstermiştir. Anne-babalar ilkokul çağlarında çocuklarının eğitimiyle daha çok ilgilendiklerinde, çocuklar anne-babalarının onlara ilkokulda gösterdikleri ilginin 
uzun süreli yararlarını lise çağlarında gördüklerini bildirmişlerdir (Epstein ve Dauber, 1991). Erdoğan ve Demirkasımoğlu (2010) araştırmasında anne-babaların çocuklarının eğitimine gösterdikleri ilginin ve okulla kurdukları iletişimin ilk sinıflarda daha sık ve yoğun olduğuna, son sınıflarda ise daha seyrek hale geldiğine işaret ederken, Catsambis ve Garland (1997) anne-babaların çocuklarının eğitimi bakımından ilkokulların ve ortaokulların sağladığı öğrenme fırsatlarıyla daha çok ilgilendiklerini ve çocukları ilkokuldan sonra ortaokula geçtiğinde, anne-babaların çocuklarının eğitimi için beklentilerinin belirginleştiğini ileri sürmüşlerdir. Öğrenciler ortaokul eğitimini tamamladıklarında, anne-babalar çocuklarına ortaokul eğitim programlarının ortaokul sonrası sunacağı fırsatlarla ve gençlerin lise eğitimiyle artan biçimde ilgilenmişlerdir.

Lise öğrencileri üzerine araştırmalarında Shumow, Lyutykh ve Schmidt (2011) annebabaların çocuklarının okuluyla ilgilenmesi ile becerikli öğrencilerin ders boyunca neler ve nasıl hissettikleri, onların not (puan) kazanımları ve uzun süreli akademik beklentileri arasındaki olumlu ilişkiyi bulmuşlardır. Chicago boylamsal araştırmasından veri kullanan Barnard (2004) çocuklarının okuluyla ilgilenerek, anne-babaların okul ile iletişim kurması, çocuklarına ders etkinliklerinde yardım etmesi ve okul etkinliklerine katılması gibi değişkenlerin, öğrencilerin liseyi bırakma olasılıklarını azalttığını, onların liseyi bitirme olasılıklarını arttırdığını ve yüksek notlar, puanlar almasını kolaylaştırdığını bulmuştur. Ergenler üzerinde araştırmalar anne-babaların çocuklarının okuluna ilgisi ile çocukların akademik başarısı arasında olumlu ilişki olduğunu vurgulamışlardır (You, Lim ve Dang, 2016). Araştırmalar, anne-babaların ilgilenme düzeyi ve onun öğrencilerin akademik başarısına etkisinin ilkokuldan lise çağına, 14-18 yaşlara kadar ilkokul, ortaokul ve lise düzeylerinde yer alan öğrenciler için aynı derecede olmadığını ileri sürmüşlerdir. Annebabaların çocuklarının okuluna ilgisi ile çocuklarının akademik başarısı arasındaki ilişkinin gücü, ilkokul öğrencilerinden 14-18 yaşlardaki lise öğrencilerine doğru düşme eğilimi göstermiştir (Singh ve diğerleri, 1995). Anne-baba ilgisinin, çoğunlukla çocuklar ortaokul ve lise öğrenimine doğru yükseldikçe azaldığı ileri sürülmesine (Desforges ve Abouchaar, 2003) karşın, anne-baba ilgisinin zorunlu olarak azalmamakla birlikte çocuklar büyüdükçe zamanla değiştiğine işaret edilmiştir. Boonk, Gijselaers, Ritzen, Brand-Gruwel (2018) çocuklara okuma ve birlikte öğrenme vb. öğrenme biçimlerine rehberlik etme, yol gösterme gibi anne-babaların doğrudan ilgisine dayalı etkinliklerin ve uygulamaların eğitimin en erken ve ilk aşamalarında çok yararlı olduğunu ve çocuklar büyüdükçe öğrenmeye rehberlik etme, yol gösterme ve yardım etme yerine anne-babaların çocuklarının akademik başarısını besleyen ve ilerleten koşulları yaratmaya çalıştıklarını ileri sürmüşlerdir. Anne-babaların yüksek akademik beklentiler koyarak ve zorla araya girmeyi ya da kontrol etmeyi düşünmeyen bir tutum ve davranış sergileyerek çocuklarının akademik motivasyonlarını ve başarılarını etkiledikleri görülmüştür.

Ülkemizde yapılan araştırmalar anne-babaların tutum ve davranışlarının, eğitime katılımlarının, anne-baba eğitim düzeyinin ve ailenin sosyo-ekonomik statüsünün öğrencilerin akademik başarısını etkilediğini ileri sürmüşlerdir (Özer ve Anıl, 2011; Şevik, 2014). Aydın, Sarıer ve Uysal (2012) anne-babaların eğitim düzeylerinin, öğrencilerin akademik başarısını etkilediğini belirtmişlerdir. Akyol, Sungur ve Tekkaya (2010) öğrencilerde akademik başarının arttırılması için, okul-aile işbirliği çerçevesinde özellikle eğitim düzeyi düşük olan anne-babaları bilinçlendirmeyi amaçlayan etkinliklerin 
düzenlenmesi gerektiğini vurgulamışlardır. Anne-babaların sosyo-ekonomik statüsü yükseldikçe öğrencilerin akademik başarılarının arttığı gözlenmiştir. Sarıer (2016) ise akademik başarıda faktörlerin etki büyüklüğünü, anne-babanın tutum ve davranışları için 0.400, sosyo-ekonomik statü düzeyi için 0.311, annenin eğitim düzeyi için 0.160, babanın eğitim düzeyi için 0.251, anne-babanın çocuklarının eğitimine katılımı ve ilgisi için 0.179 olarak bulmuştur. Anıl (2009) araştırmasında anne-babaların eğitim düzeyi ile öğrencilerin fen bilimleri başarı puanı arasında olumlu bir ilişkinin olduğunu ve sahip oldukları eğitim düzeylerinin anne-babaların çocuklarının lise eğitimiyle ilgilenme derecesini etkilediğini bulmuştur. Eğitim düzeyleri yükseldikçe anne-babaların çocuklarının lise eğitimiyle ilgilenme derecesi artmıştır. Salıcı-Ahioğlu (2006) sosyo-ekonomik düzeyleri yükseldikçe anne-babaların evde çocuklarına ilk okuma yazma becerilerini kazandırmayı amaçlayan çabalarını arttırdıklarını ve çocuklarının eğitimi ile ilgili olası sorunların çözümünde öğretmenlerle işbirliği yaptıklarını bulmuştur. Elmacıoğlu (1998) ise araştırmasında daha eğitimli anne-babaların, çocuklarındaki başarı güdüsünü harekete geçirmede daha etkili olduklarını, görece başarısız öğrencilerin anne-babaları ile karşılaştırıldığında başarılı öğrencilerin çoğunun anne-babalarının eğitim düzeylerinin yüksek olduğunu bildirmiştir. Araştırmada anne-babaların sahip oldukları eğitim düzeylerinin çocuklarını ders çalışmaya teşvik etmede ve onlara ev ödevlerini hazırlaması için yardım etmede önemli ve etkili olduğu belirtilmiştir. İlköğretim okulu öğrencilerinin başarısında aile faktörünün etkisini ele alan bir araştırmasında Hakan (2001) çocuklarının akademik başarısı yüksek olan annebabaların okulla, öğretmenlerle ilişkilerinin iyi olduklarını, çocuklarının eğitimiyle yakından ilgilendiklerini ve çocuklarına gerekli eğitim-öğretim ortamını ve fırsatlarını sunduklarını bulmuştur. Çocuklarının akademik başarısı görece düşük olan anne-babalar, çocuklarının eğitimiyle yeterli biçimde ilgilenmediklerini söylemişlerdir. Bir araştırmada anne-babalar kendi işlerinin çokluğu ve eğitim düzeylerinin yetersizliği nedeniyle çocuklarının okuluyla yeterli biçimde ilgilenemediklerini bildirmişlerdir. Anne-babalar, öğretmenlerin otoriter davranmasından, sürekli öğüt vermesinden ve okulda resmi bir havanın hâkim olmasından yakındıklarını söylemişlerdir. Araştırma, okul yönetimlerinin ve öğretmenlerin okul ile anne-babalar arasında kurulan olumlu iletişimin, öğrencilerin akademik başarısını arttırabileceği ve okuldaki bazı sorumlulukların velilere aktarılabileceği gibi bir düşünceyi, yeterli biçimde anlayamadıklarına işaret etmiştir (Aslanargun, 2007). Bir diğer araştırmada Şahin (2019) anne-babaların çocuklarının eğitim sürecine ilgisini ve katılımını sağlamanın en yaygın yollarından birisinin veli toplantıları olduğunu ileri sürmüştür. Araştırmada annebabaların çocuklarının disiplin sorunları, onlardan yakınma, okul yönetimlerinin veli olarak anne-babalardan okula ekonomik ya da parasal olarak yardım etme beklentileri gibi nedenlerle çağrıldıklarını düşündükleri için veli toplantılarına katılmada isteksiz oldukları görünmüştür. Araştırmada veli toplantılarında görüşülecek gündem maddelerini önceden anne-babalara bildirme, okulda anne-babaları sıcak ve saygıyla karşılama ve yaklaşma, onları suçlamaktan ve eleştirmekten çok onlarla iletişimde yapıcı bir dil kullanma gibi tutum ve davranışların anne-babaların veli toplantılarına katılımını arttırabileceği sonucuna ulaşılmıştır.

\section{Anne-Babaların Çocuklarının Eğitimi ve Akademik Başarı Beklentileri ve İstekleri İle Çocukların Akademik Başarısı Arasındaki İlişki}

Araştırmacılar anne-babaların çocuklarının eğitimi ve akademik başarısı için beklentilerini ve isteklerini, onların çocuklarına gösterdikleri ilginin boyutlarından biri olarak kabul 
etmişler ve bir değişken olarak ele almışlardır. Araştırmalar, anne-babaların, çocuklarından daha yüksek notlara, puanlara, daha yüksek eğitim kazanımına, daha yüksek akademik başarıya sahip olmalarını ve üniversiteyi kazanmayı beklediklerini ve istediklerini göstermişlerdir. Anne-babaların çocuklarının eğitimi ve akademik başarısı için beklentileri ve istekleri ile çocuklarının akademik başarısı arasında olumlu bir ilişkinin olduğu belirlenmiştir (Phillipson S. ve Phillipson S. N., 2012; Shute ve diğerleri, 2011). Annebabaların çocuklarına evde ve okul yönünde gösterdikleri ilginin düzeyini ve etkisini inceleyen bir araştırmada Lee ve Bowen (2006) bu ilgi değişkenlerinin birlikte, demografik değişkenlerin etkilerinin ötesinde okumada ve matematik başarısında değişmenin \% 9'nu açıkladığını bulmuşlar ve anne-babaların bir ilgi türü olarak çocuklarından eğitimsel beklentilerinin öğrencilerin akademik başarısını en güçlü bir biçimde etkilediği sonucuna ulaşmışlardır. Chen ve Gregory (2010) ise yaptıkları araştırmada anne-babaların diğer ilgi türleri göz önüne alındığında, cinsiyet ve etni-site kontrol edildikten sonra, ilgi değişkenleri arasında anne-babaların çocuklarının eğitimi ve akademik başarısı için beklentilerinin öğrencilerin akademik başarısını anlamlı biçimde en güçlü olarak etkilediğini bulmuşlardır. Araştırmacılar anne-babalarının onların eğitimsel kazanımı için daha düşük eğitimsel beklentilere sahip olduklarını bildiren akranları ile karşılaştırıldığında anne-babalarının onların eğitimsel kazanımı için daha yüksek eğitimsel beklentilere sahip olduklarını bildiren öğrencilerin daha yüksek genel not ortalamalarına sahip olduklarını ve öğretmenleri tarafından sınıfta derslerle daha çok meşgul olan öğrenciler olarak değerlendirildiklerini bulmuşlardır. Genellikle anne-babaların çocuklarının eğitimi ve akademik başarısı için beklentileri ile öğrencilerin akademik başarısı arasında olumlu bir ilişkinin olduğu gözlenmiştir (You ve diğerleri, 2016). Meta çözümleme yapan araştırmalar da anne-babaların beklentilerinin öğrencilerin akademik başarılarını belirgin biçimde etkilediklerini doğrulamıştır (Jeynes, 2007; Wilder, 2014). Bu araştırmalar, çocuklarının eğitimi ve akademik başarısı için yüksek beklentilerini sürdürdüklerinde anne-babaların çocuklarına kitaplar, dergiler ve diğer eğitimsel materyaller gibi kaynakları sağladıklarını, çocuklarına okulda verilen ev ödevlerinde yardım ettiklerini, onları kütüphaneye ve hayvanat bahçesine götürdüklerini göstermiştir. Bu anne-babaların çocuklarını bilişsel olarak teşvik eden ve geliştiren bu tür etkinliklerle daha çok meşgul oldukları görülmüştür. Alexander ve Entwistle (1996) ise araştırmalarında anne-babalar çocuklarının eğitimi ve eğitimdeki başarısı için beklentilerini onlara ilettiklerinde, çocuklarının eğitimine gösterdiği ilginin ortaokul ve lise öğrencileri ile karşılaştırıldığında ilkokul öğrencilerini daha çok ve daha belirgin biçimde etkilediği sonucuna ulaşmışlardır. Diğer bir araştırmada Sanders ve Sheldon (2009) anne-babalar beklentilerini çocuklarına ilettiklerinde, onlarla okul ve gelecekteki planları hakkında tartıştıklarında, onların okulda verilen ev ödevlerini kontrol ettiklerinde, çocuklarının İngilizce ve okuma başarı testlerinden daha yüksek notlar, puanlar aldıklarını bulmuşlardır. Davis-Kean (2005) ise araştırmasında genelde görece olarak düşük beklentileri sürdüren anne-babaların çocuklarıyla karşılaştırıldığında yüksek beklentileri sürdüren anne-babaların çocuklarının okulda daha iyi performans gösterdikleri ve okulda daha uzun süre kalarak öğrenme etkinliklerine katıldıkları sonucuna varmıştır. Eccles (2005) anne-babaların orta yaş çocuklarının başarı anlayışı ve inancı üzerindeki beklentilerini değerlendirdiği araştırmasında anne-babaların beklentilerinin çocukların kendi yeteneklerine inanmasını ve kendi yeterlilik duygusunu arttırdığını, onların yeteneklerini ve kapasitelerini etkilediğini ve böylece öğrencilerin başarısında dolaylı biçimde olumlu bir rol oynadığını bulmuştur. 9-16 yaş arasındaki çocuklarla ilgili bir araştırma anne-babaların 
beklentilerinin öğrencilerin matematik ve okuma alanında yeni bir kavramı öğrenmesi için kendi akademik beceri ve yeteneği yönündeki algısını etkilediği sonucuna ulaşmıştır (Yamamoto ve Holloway, 2010). Diğer bir araştırmada Singh ve diğerleri (1995) anne-baba ilgisinin dört boyutuna (a) anne-babaların çocuklarının eğitimi ve akademik başarısı için isteklerine, (b) anne-babaların-çocuklarıyla okul hakkındaki iletişimlerine, (c) aile yapısına, (d) anne-babaların okulla ilişkili etkinliklere katılımına işaret etmişlerdir. Anne-babaların bu dört ilgi boyutu ve yönünün 8. sınıf öğrencilerinin akademik başarısı üzerindeki etkisini inceleyen araştırmada çocuklarıyla okul konularını konuşan ve tartışan anne-babaların öğrencilerin okul başarısını orta düzeyde olumlu bir biçimde etkiledikleri belirlenirken, anne-babaların çocuklarının eğitimi ve akademik başarısı için onlardan isteklerinin ise öğrencilerin okul başarısı ile en güçlü ve olumlu biçimde ilişkili olduğu görünmüştür. Gill ve Reynolds (1999) ise araştırmalarında anne-babalar çocuklarına ortaokulda derslerini iyi yapması ve başarılı olması yönündeki beklentilerini ilettiklerinde, çocuklarının okuma ve matematik beceri testlerinden anlamlı bir biçimde daha yüksek puanlar aldıklarını bulmuşlardır. 6-13 yaş çocukları ile ilgili bir boylamsal araştırmada ise anne-babaların beklentilerinin çocukların beklentilerini uzun süre belirgin bir biçimde etkilediği sonucuna ulaşılmıştır. Anne-babaların sahip olduğu eğitimsel beklentilerin çocukların beklenti düzeylerini arttırdığı ve 5 yıl sonra çocuklarının akademik performansında olumlu bir rol oynadığı görülmüştür (Rutchick, Smyth, Lopoo ve Dusek, 2009). Diğer bir araştırmada Sy, Rowley ve Schulenberg (2007) çocuklarının eğitimsel kazanımı yönünde daha yüksek beklentileri olan ve bu beklentilere daha yüksek bir değer veren anne-babaların çocuklarının okumasına yardım etme, ders programları dışında onlara ders sunma ve onların eğitimsel süreçlerini izleme, kontrol etme gibi etkinliklerle daha çok meşgul olduklarını bulmuşlardır

\section{Sonuç}

Anne-babaların değerleri ve eğitim istekleri, onların eğitim alanındaki ilgisini ortaya çıkarmakta ve bu ilgi, çocukların akademik performansında önemli bir rol oynamaktadır. Eğitime ilişkin değerler, istekler ve beklentiler, sürekli olarak çocukları sosyalleştirmenin ve yetiştirmenin olumlu uygulamalarında görülmektedir. Çocuklar, sosyalleşme sürecinde eğitimle ilgili değerleri, istekleri ve beklentileri algilamakta, içselleştirmekte ve benimsemektedir. $\mathrm{Bu}$ değerler, istekler ve beklentiler, çocukların motivasyonunu, kendine güvenini ve eğitim isteklerini etkilemektedir. Anne-babalar beklentileriyle çocuklarında öğrenme motivasyonunu yükseltmekte, öğrencilerin kendi yeteneklerine güvenini ve inançlarını arttırmakta ve çocuklarını daha çok öğrenmeye teşvik etmektedir. Onlar çocuklarının eğitimiyle, öğretmenleriyle ve okuluyla ilgilendiklerinde ve bu yönde olumlu tutumlar sergilediklerinde, çocuklarının akademik performansı artmaktadır. Akademik performans hem standart başarı testleriyle hem de öğretmenlerin sınıfta öğrencilerin akademik performansını değerlendirmesiyle ölçülmektedir. Anne-baba ilgisi ile çocukların akademik başarısı arasındaki en güçlü ilişkiler, anne-babalar çocukları için yüksek ve açık akademik beklentilere sahip olduklarında, okul etkinlikleri ve dersler hakkında çocuklarıyla iletişimi kurduklarında ve sürdürdüklerinde, onlarda okuma alışkanlıklarını ilerlettiklerinde ortaya çıkmaktadır. Anne-babalar, onlarla ilgilenerek, ana amaç olarak onların öğrenmesini ve çalışmasını sağlamak için çocuklarının yanında olmakta ve onları denetlemektedir. Onlar çocuklarının akademik başarısı için yüksek beklentilerini ve isteklerini sürdürmekte, okulla ilgili olarak çocuklarıyla konuşmakta, evde çocuklarına okumakta, öğrenmesi için onları teşvik etmekte ve desteklemektedir. 


\section{Öneriler}

Anne-babalar, çocuklarının eğitiminde ve onların akademik başarısını arttırmada aktif bir rol oynayabilmelidir. Onlar, çocuklarında yaşamda gerekli becerileri geliştirebilen ve okulda öğrenilenleri pekiştiren ve öğrenmeyi ilerleten bir aile çevresi yaratabilmelidir. Annebabalar, çocuklarının okulu ve eğitimi için onların bilgisine ve becerilerine katkı yapabilmelidir. Onlar çocuklarının eğitimini teşvik etmek, desteklemek ve ekstra hizmetler sağlamak için gerekli tutum ve davranışları gösterebilmelidir. Anne-babalar, çocuklarına evde çalışması için zaman ayırma ve sessiz yer sağlama, çocuklarının okuldaki akademik gelişimini ve ilerlemesini teşvik etme, ev ödevinde onlara yardım etme, onlarla iyi bir eğitimin ve mesleğin değerini tartışma gibi çocuklarının akademik başarısına katkı sağlayacak etkinlikleri ve uygulamaları yapabilmelidir. Onlar, okul etkinliklerinin dişında çocuklarını izleme ve çocuklarının televizyon seyretmesine sınırlar koyma eğilimini gösterebilmelidir. Anne-babalar, çocuklarına oyun oynamaya zaman ayırmakla birlikte oyun oynama ve ders çalışma süreleri arasındaki dengeyi korumaları gerektiğini söyleyebilmelidir. Sosyalleştirme ve çocuk yetiştirme süreçlerinde kontrol ya da sıkılık boyutunun bir gereği olarak anne-babalar, çocuklarının ilişki ve etkileşim içerisinde oldukları çevreleri ve kimlerle arkadaşlık ettiklerini bilmeye ve tanımaya çalışmalıdır. Onlar, çocukları ile sıcak, sevgi dolu ve destekleyici bir ilişkiyi ve etkileşimi sürdürebilmeli ve çocuklarını ileride sorumlu yetişkinler olacak biçimde büyütülebilmelidir.

\section{Gelecekteki Araştırmalar için Öneriler}

Anne-babaların çocuklarının eğitimine gösterdiği ilginin okul öncesi, ilkokul, ortaokul ve lise dönemlerinde etkisinin farklı olduğu ve değişebildiği tartş̧ılmaktadır. Anne-babaların çocuklarıyla birlikte şarkı söyleme ya da oyunlar oynama gibi evde öğrenme etkinlikleriyle meşgul olmaları ile küçük çocukların akademik başarısı arasında tutarlı ve olumlu biçimde ilişki olduğu belirlenirken, bu ilgi davranışlarının daha büyük çocuklar için daha uzun süre yararlı olmadığı ileri sürülmektedir. Öğrencilerin performansını ve çabalarını övme, onları akademik olarak teşvik etme ve destekleme, anne-babaların çocuklarının eğitiminden ve akademik başarısından yüksek beklentileri gibi anne-babaların ilgi yönleri ve boyutlarının ise ortaokul ve lise öğrencileri üzerinde daha etkili ve yararlı olduğu tartışılmaktadır. Gelecekteki araştırmalar anne-baba ilgisinin hangi yön ve boyutlarının okul öncesi, ilkokul, ortaokul ve lise dönemlerindeki öğrenciler için daha etkili ve yararlı olduğunu belirlemeye çalışmalıdır. Araştırmalar anne-babaların çocuklarının eğitimine ilgi düzeyleri yüksek olur ise daha çok eğitimli ve daha az eğitimli annelerin çocukları arasındaki başarı farklarının, uçurumlarının azaldığını ileri sürmektedir. Bu bakımdan gelecekteki araştırmalar, annebabaların çocuklarının eğitimine ilgisi ile çocuklarının akademik başarısı arasındaki ilişkide sosyoekonomik statünün oynadığı role daha çok odaklanmalıdır. Araştırmacılar, çocuklarının eğitimine daha çok ilgi göstermesi için düşük eğitimli anne-babalara nasıl yol gösterileceği ve ne tür davranış ve etkinliklerle çocuklarının eğitimine yardım edebilecekleri ve böylece çocuklarının akademik başarısına katkı yapan bir çevreyi nasıl sağlayacakları gibi konulara daha çok yoğunlaşmalıdır. 


\section{Kaynakça}

Akın, A. (2009). Algılanan anne-baba tutumlarının öğrencilerin sosyal bilgiler dersindeki akademik başarıları üzerine etkisi (Yüksek lisans tezi. Sakarya Üniversitesi, Sakarya).

Akyol, G., Sungur, S., \& Tekkaya, C. (2010). The contribution of cognitive and metacognitive strategy use to students' science achievement. Educational Research and Evaluation,16, 1-21.

Alexander Karl, L., \& Entwisle Doris, R. (1996). Family type and children's growth in reading and math over the primary grades. Journal of Marriage and Family, 58(2), 341-355.

Alkan Ersoy, Ö. (2018). Aile parçalanmasının çocuğun okul başarısına etkisi: Trabzon örneği. Karadeniz Araştırmaları Enstitüsü Dergisi, 4(5), 167-225.

Altschul, I. (2011). Parental involvement and the academic achievement of Mexican American youths: What kinds of involvement in youths' education matter most? Social Work Research, 35, 159-170.

Anıl, D. (2009). Uluslararası öğrenci başarılarını değerlendirme programı (PISA)'nda Türkiye'deki öğrencilerin fen bilimleri başarılarını etkileyen faktörler. Eğitim ve Bilim, 34(152), 87-100.

Arcan K. (2006). Özel okullara giden lise düzeyindeki ergenlerin, akademik başarıları ile algıladıkları anne baba tutumlar arasındaki ilişkilerin incelenmesi (Yüksek lisans tezi, Maltepe Üniversitesi, İstanbul).

Aslanargun, E. (2007). Okul-aile işbirliğgi ve öğrenci başarısı üzerine kuramsal bir çalışma. Sosyal Bilimler Degisi, 18, 119-135.

Aunola, K., Stattin, H., \& Nurmi Jarı, E. (2000). Parenting styles and adolescents' achievement strategies. Journal of Adolescence, 23, 205-222.

Aydın, A., Sarıer, Y., \& Uysal, Ş. (2012). Sosyoekonomik ve sosyokültürel değiş̧kenler açısından PISA matematik sonuçlarının karşılaştırılması. Ĕ̆itim ve Bilim, 164(37), 20-30.

Balcı, A. (1988). Etkili okul. Eğitim ve Bilim, 70, 21-30.

Barnard Wendy, M. (2004). Parent involvement in elementary school and educational attainment. Children and Youth Services Review, 26(1), 39-62.

Baumrind, D. (1967). Child care practices anteceding three patterns of preschool behavior. Genetic Psychology Monographs, 75, 43-88.

Baumrind, D. (1978). Parental disciplinary patterns and social competence in children. Youth and Society, 9, 239-276.

Baumrind, D. (1991). The influence of parenting style on adolescent competence and substance use. Journal of Early Adolescence, 11, 56-95.

Bekman, S. (1998). Eşit firsat: Anne çocuk eğitim programı'nın değerlendirilmesi. İstanbul: Anne Çocuk Eğitim Vakfı Yayınları.

Boonk, L., Gijselaers Hieronymus, J.M., Ritzen, H., \& Brand -Gruwel, S. (2018). A review of the relationship between parental involvement indicators and academic achievement. Educational Research Review, 24, 10-30. 
Bryan, J. (2005). Fostering educational resilience and achievement in urban schools through schoolfamily community partnerships Partnerships/Community. 22. https://digitalcommons.unomaha.edu/slcepartnerships/22

Catsambis, S., \& Garland Janet, E. (1997). Parental involvement in students' education during middle school and high school (Report No: 18). Queens College and CUNY Graduate Center.

Chen Wei, B., \& Gregory, A. (2010). Parental involvement as a protective factor during the transition to high school. The Journal of Educational Research, 103, 53-62.

Clark Reginald, M. (1993). Homework-focused parenting practices that positively affect achievement. In N. F. Chavkin, (ed.), Families and schools in a pluralistic society (pp. 85-105). Albany: State University of New York Press.

Cooper, H., Lindsay James, J., Nye, B., \& Greathouse, S. (1998). Relationships among attitudes about homework, amount of homework assigned and completed, and student achievement. Journal of Educational Psychology, 90, 70-83.

Crosby Susan A., Rasinski, T., Padak, N., \& Yıldırım, K. (2015). A 3-year study of a schoolbased parental involvement program in early literacy. The Journal of Educational Research, $108,165-172$.

Çelenk, S. (2003). Okul-aile işbirliği ile okuduğunu anlama arasındaki ilişki. Hacettepe Üniversitesi Eğitim Fakültesi Dergisi, 24, 3-39.

Çiftçi, M., \& Nedim Bal, P. (2015). Ortaokul öğrencilerinin anne-baba katılım düzeyi ile akademik başarıları arasındaki ilişkinin incelenmesi. International Journal of Human Sciences, 12(1), 363-384.

Davis-Kean Pamela, E. (2005). The influence of parent education and family income on child achievement: The indirect role of parental expectations and the home environment. Journal of Family Psychology, 19(2), 294-304.

Dearing, E., Kreider, H., Simpkins, S., \& Weiss Heather, B. (2006). Family involvement in school and low-income children's literacy: Longitudinal association between and within families. Journal of Educational Psychology, 98, 653-664.

Deslandes, R., Royer, E., Turcotte, D., \& Bertrand, R. (1997). School achievement at the secondary level: Influence of parenting style and parent involvement in schooling. Mcgill Journal of Education, 32(3), 191-208.

Desforges, C., \& Abouchaar, A. (2003). The impact of parental involvement, parental support and family education on pupil achievement and adjustment: A literature review. London: Department for Education and Skills.

Deutscher, R., \& Ibe, M. (2004). In what way does parent involvement affect children's academic performance? Apple Valley, CA: Lewis Center for Educational Research.

Dornbusch Sanford, M., Ritter P. L., Leiderman, P.H., Roberts, D.F., \& Fraleigh, M.J. (1987). The relation of parenting style to adolescent school performance. Child Development, 58, 1244-1257.

Driessen, G., Smith, F., \& Sleegers, P. (2005). Parental involvement and educational achievement. British Educational Research Journal, 31(4), 509-532. 
Eccles Jacquelynne, S. (2005). Influences of parents' education on their children's educational attainments: The role of parent and child perceptions, London Review of Education, 3(3), 191-204.

Elmacıoğlu, T. (1998). Başarıda Aile Faktörü, İstanbul: Hayat Yayınları.

Epstein Joyce, L., \& Dauber Susan L. (1991). School programs and teacher practices of parent involvement in inner-city elementary and middle schools. Element. School Journal, 91, 289305.

Epstein Joyce, L. (2001). School, family, and community partnerships: Preparing educators and improving schools. Boulder, CO: Westview.

Erdoğan, Ç., \& Demirkasımoğlu, N. (2010). Ailelerin eğitim sürecine katılımına ilişkin öğretmen ve yönetici görüşleri. Kuram ve Uygulamada Eğitim Yönetim, 16(3), 399-431.

Erdoğdu, M.Y. (2007). Ana-baba tutumları ve öğretmen davranışları ile öğrencilerin akademik başarıları arasındaki ilişkiler. Sakarya Üniversitesi Eğitim Fakültesi Dergisi, 14, 33 46.

Feurstein, A. (2000). School characteristics and parent involvement: Influencees on participation in children's schools. The Journal of Educational Research, 94, 29-40.

Gill, S., \& Reynolds Arthur, J. (1999). Educational expectations and school achievement of urban African American children. Journal of School Psychology, 37(4), 403-424.

Gonida, E., \& Cortina Kai, S. (2014). Parental involvement in homework: Relations with parent and student achievement-related motivational beliefs and achievement. British Journal of Educational Psychology, 84, 376-396.

Graves Scott, L., \& Wright Jr.Lynda, B. (2011). Parent involvement at school entry: A national examination of group differences and achievement. School Psychology International, 32(1), $35-48$.

Hakan, A. (2001). İlköğretim okulu öğrencilerinin başarısında aile faktörü (Yüksek lisans tezi. Sakarya Üniversitesi, Sakarya). https://www.ulusaltezmerkezi.net/search-

Halle Tamara, G., Kurtz-Costes, B., \& Mahoney Joseph, L. (1997). Family influences on school achievement in low-income, African American children. Journal of Educational Psychology, 89(3), 527-537.

Hayes, D. (2012). Parental involvement and achievement in African American adolescents. Journal of Comparative Family Studies, 43, 567-582.

Hemmerechts, K., Ağırdağ, O., \& Kavadias, D. (2017). The relationship between parental literacy involvement. Socio-economic status and reading literacy. Educational Review, 69, 85-101.

Hill Nancy, E., \& Craft Stacie, A. (2003). Parent-school involvement and school performance: Mediated pathways among socioeconomically comparable African American and EuroAmerican families. Journal of Educational Psychology, 95(1), 74-83.

Hill Nancy, E., \& Taylor Lorraine, C. (2004). Parental school involvement and children's academic achievement: Pragmatics and issues. Current Directions in Psychological Science, 13, 161-164. 
Hill Nancy, E., \& Tyson Diana, F. (2009). Parental involvement in middle school: A metaanalytic assessment of the strategies that promote achievement. Developmental Psychology, 45(3), 740-763.

Ho Esther Sui, C. (2010). Family influences on science learning among Hong Kong adolescents: What we learned from PISA. International Journal of Science and Mathematics Education, 8, 409-428.

Holloway Susan, D., Yamamoto, Y., Suzuki, S., \& Mindnich Jessica, D. (2008). Determinants of parental involvement in early schooling: Evidence from Japan. Early Childhood Research and Practice, 10(1), 1-10.

İpek, C. (2011). Velilerin okul tutumu ve eğitime katılım düzeyleri ile aileye bağlı bazı faktörlerin ilköğretim öğrencilerinin seviye belirleme sınavları (SBS) üzerindeki etkisi. Pegem Ĕ̈itim ve Öğretim Dergisi, 1(2), 69-79.

Jaiswal Kumar, S., \& Choudhuri, R. (2017). A review of the relationship between parental involvement and students' academic performance. The International Journal of Indian Psychology, 4(3), 110-123.

Jeynes Willam, H. (2007). The relationship between parental involvement and urban secondary school student academic achievement: A meta-analysis. Urban Education, 42, 82110.

Katz, I., Kaplan, A., Buzukashvily, T. (2011). The role of parents' motivation in students' autonomous motivation for doing homework. Learning and Individual Differences, 21, 376386.

Keçeli Kaysılı, B. (2008). Akademik başarının arttırılmasında aile katılımı. Ankara Üniversitesi Eğitim Bilimleri Fakültesi Özel Eğitim Dergisi, 9(1), 69-83.

Keith Timothy, Z., Keith Patricia, B., Troutman Gretchen, C., \& Bickley Patricia, G. (1993). Does parental involvement affect eighth-grade student achievement? Structural analysis of national data. School Psychology Review, 22, 474-496.

Kellaghan, T., Sloane, K., Alvarez, B., \& Bloom Benjamin, S. (1993). The home environment and school learning: Promoting parental involvement in the education. San Francisco, CA, US: Jossey-Bass.

Kim, K., \& Rohner Ronald, P. (2002). Parental warmth, control, and involvement in schooling: Predicting academic achievement among Korean American adolescents. Journal of Cross-Cultural Psychology, 33(2), 127-140.

Kloosterman, R., Notten, N., Tolsma, J., \& Kraaykamp Gerbert, L. (2011). The effects of parental reading socialization and early school involvement on children's academic performance: A panel study of primary school pupils in the Netherlands. European Sociological Review, 27, 291-306.

Kohl Gwynne, O., Lengua Lilliana, J., \& McMahon Robert, J. (2000). Parent involvement in school conceptualizing multiple dimensions and their relations with family and demographic risk factors. Journal of School Psychology, 38(6), 501-523. 
Lamborn Susie, D., Mounts Nina, S., Steinberg, L., \& Dornbusch Sanford, M. (1991). Patterns of competence and adjustment among adolescents from authoritative, authoritarian, indulgent, and neglectful families. Child Development, 62, 1049-1065.

Lee Jung, S., \& Bowen Natasha, K. (2006). Parent involvement, cultural capital, and the achievement gap among elementary school children. American Educational Research Journal, 43,193-218.

Maccoby Eleanor, E. (2000). Parenting and its effects on children: On reading and misreading behavior. Annual Review of Psychology, 51, 1-27.

Manolitsis, G., Georgiou George, K., \& Tziraki, N. (2013). Examining the effects of home literacy and numeracy environment on early reading and math acquisition. Early Childhood Research Quarterly, 28, 692-703.

Marchant Gregory, J., Paulson Sharon, E., \& Rothlisberg Barbara, A. (2001). Relations of middle school students' perceptions of family and school contexts with academic achievement. Psychology in the Schools, 38(6), 505-519.

McNeal Jr Ralph, B. (2014). Parent involvement, academic achievement and the role of student attitudes and behaviors as mediators. Universal Journal of Educational Research, 2(8), 564-576,

Miedel Wendy, T., \& Reynolds, A. (1999). Parent involvement in early intervention for disadvantaged children: Does it matter? Journal of School Psychology, 37(4), 379-402.

Mo, Y., \& Singh, K. (2008). Parents' relationships and involvement: Effects on students' school engagement and performance RMLE Online, Research in Middle Level Education, 31(10), 1-11.

Moroni, S., Dumont, H., Trautwein, U., Niggli, A., \& Baeriswly, F. (2015). The need to distinguish between quantity and quality in research on parental involvement: The example of parental help with homework. The Journal of Educational Research, 108, 417-431.

Nyarko, K. (2011). The influence of authoritative parenting style on adolescents' academic achievement. American Journal of Social and Management Sciences, 2(3), 278-282.

Özdayı, N. (2004). Öğrenci ve öğretmenlerin gözüyle sınıf yönetimi sorunlarına genel bir bakış XII. Eğitim Bilimleri Kongresi Bildirileri, 1, 375-394. Ankara: Gazi Üniversitesi Eğitim Bilimleri Enstitüsü.

Özer Özkan, Y., \& Anıl, D. (2011). Öğrencilerin fen ve matematik başarılarını etkileyen faktörlerin yapısal eşitlik modeli ile incelenmesi. Hacettepe Üniversitesi Eğitim Fakültesi Dergisi, 41,313-324.

Patall Erika, A., Cooper, H., \& Robinson Jorgianne, C. (2008). Parent involvement in homework: A research synthesis. Review of Educational Research, 78, 1039-1101.

Paulson Sharon, E. (1994). Relations of parenting style and parental involvement with ninthgrade students' achievement. Journal of Early Adolescence, 14, 250-267.

Pena Delores, C. (2000). Parent involvement: influencing factors and implications. The Journal of Educational Research, 94(1), 42-56. 
Phillipson, S., \& Phillipson Shane, N. (2012). Children's cognitive ability and their academic achievement: The mediation effects of parental expectations. Asia Pacific Education Review, 13, 495-508.

Regner, I., Loose, F., Dumas, F. (2009). Students' perceptions of parental and teacher academic involvement: Consequences on achievement goals. European Journal of Psychology of Education, 24(2), 263-277.

Rimm-Kaufman Sara, E., Pianta Robert, C., Cox Martha, J., \& Bradley Robert, H. (2003). Teacher-rated family involvement and children's social and academic outcomes in kindergarten. Early Education and Development, 14(2), 179-198.

Rutchick Abraham, M., Smyth Joshua, M., Lopoo Leonard, M., \& Dusek Jerome, B. (2009). Great expectations: The biasing effects of reported child behavior problems on educational expectancies and subsequent academic achievement. Journal of Social and Clinical Psychology, 28(3), 392-413.

Salıc1 Ahioğlu, Ş. (2006). Öğretmen ve veli görüşlerine göre farklı sosyoekonomik düzeydeki ailelerin ilköğretim birinci sını öğrencilerinin okuma yazma sürecini etkileme biçiminin değerlendirilmesi (Yüksek lisans tezi, Çukurova Üniversitesi, Adana). https://www.ulusaltezmerkezi.net/ilkogretim-okullarinda-aile-katilimi-olcek-uyarlamasi

Sanders Mavis, G., \& Sheldon Steven, B. (2009). Principals matter: A guide to school, family, and community partnerships. Corwin: A SAGE Company.

Sarıer, Y. (2016). Türkiye'de öğrencilerin akademik başarısını etkileyen faktörler: Bir metaanaliz çalışması. Hacettepe Üniversitesi Eğitim Fakültesi Dergisi, 31(3), 1-19.

Satır, S. (1996). Özel Tevfik Fikret lisesi öğrencilerinin akademik başarılarılyla ilgili anne-baba davranışları ve akademik başarıy artırmaya yönelik anne-baba eğitim gereksinmelerinin belirlenmesi (Yüksek lisans tezi, Ankara Üniversitesi, Ankara). https://www.ulusaltezmerkezi.net/search-

Savaş, E., Taş, S., \& Duru, A. (2010). Matematikte öğrenci başarısnı etkileyen faktörler. İnönü Üniversitesi Ĕ̆itim Fakültesi Dergisi, 11, 113-132.

Shumow, L., Lyutykh, E., \& Schmidt Jennifer, A. (2011). Predictors and outcomes of parental involvement with high school students in science. The School Community Journal, 21(2), 8198.

Shute Valerie, J., Hansen Eric, G., Underwood Jody, S., \& Razzouk, R. (2011). A Review of the relationship between parental involvement and secondary school students' academic achievement. Education Research International, 2011, 1-10.

Sibley, E., \& Dearing, E. (2014). Family educational involvement and child achievement in early elementary school for American born and immigrant families. Psychology in the Schools, 51, 814-831.

Singh, K., Beckley, P., Trivette, P., Keith Timothy, Z., Keith, P., \& Anderson, E. (1995). The effects of four components of parental involvement on eighth grade student achievement: structural analysis of NELS-88 data. School Psychology Review, 24, 299-317. 
Steinberg, L., Lamborn Susie, D., Dornbusch Sanford, M., \& Darling, N. (1992). Impact of parenting practices on adolescent achievement: Authoritative parenting, school involvement and encouragement to succeed. Child Development, 63(5), 1266-1281.

Sui-Chu Ester, H., \& Willms Douglas, J. (1996). Effects of parental involvement on eighthgrade achievement. Sociology of Education, 69(2), 126-141.

Sy Susan, R., Rowley Stephanie, J., \& Schulenberg John, E. (2007). Predictors of parent involvement across contexts in Asian American and European American families. Journal of Comparative Family Studies, 38(1), 1-29.

Şad Süleyman, N. (2012). Investigation of parental involvement tasks as predictors of primary students' Turkish, math, and science and technology achievement. Eğitim Araştırmalart- Eurasian Journal of Educational Research, 49, 173-196.

Şahin, H. (2019). Öğrenmeyi destekleyici ortamının veli toplantılarında yer alma durumunun incelenmesi. Küreselleşme Sürecinde Teknolojik Yenilikler ve Eğitim Araştırmaları, 26-60, https://www.researchgate.net/profile/Recep_Kahramanoglu/publication/330113281_ .pdf?origin=publication_detail

Şentürk, Ü. (2012). Sosyolojik açıdan parçalanmış aile ve çocuk ilişkisi, İstanbul: Kum Saati Yayınlar1.

Şevik, Y. (2014). Illköğretim müdür ve müdür yardımcılarının öğrencilerin akademik başarısını etkileyen faktörlere ilişkin görüşleri ile akademik başarısına katkıları (Yüksek lisans tezi, Mehmet Akif Üniversitesi, Burdur). https://www.ulusaltezmerkezi.net/search-

Tam Vicky, C., \& Chan Raymond, M. (2009). Parental involvement in primary children's homework in Hong Kong. The School Community Journal, 19(2), 81-100.

Tan Edwin, T., \& Goldberg Wendy, A. (2009). Parental school involvement in relation to children's grades and adaptation to school. Journal of Applied Developmental Psychology, 30, 442-453.

Topor David, R., Keane Susan, P., Shelton Terri, L., \& Calkins Susan, D. (2010). Parent involvement and student academic performance: A multiple mediational analysis. Journal Prevention and Intervention Community, 38(3), 183-197.

Vural, B. (2004). Okul başarısında ailenin rolü ve önemi. İstanbul: Bilgi Yayınevi.

Wen, X., Bulotsky Shearer, R., Hahs Vaughn Debble, L., \& Korfmacher, J. (2012). Head start program quality: Examination of classroom quality and parent involvement in predicting children's vocabulary, literacy and mathematics achievement trajectories. Early Childhood Research Quarterly, 27(4), 640-653.

Wilder, S. (2014). Effects of parental involvement on academic achievement: A meta synthesis. Educational Review, 66(3), 377-397.

Wynn, T. (2002). Archaeology and cognitive evolution. Behavioral and Brain Sciences, 25(3), 389-402.

Yamamoto, Y., \& Holloway Susan, D. (2010). Parental expectations and children's academic performance in sociocultural context. Educational Psychology Review, 22(3), 189-214. 
Yılmaz, A. (2000). Eşler arasındaki uyum ve çocuğun algıladığı anne-baba tutumu ile çocukların, ergenlerin ve gençlerin akademik başarıları ve benlik algıları arasındaki ilişkiler (Doktora tezi, Hacettepe Üniversitesi, Ankara). https://www.ulusaltezmerkezi.net/search-

You, S., Lim Sun, A., No, U., \& Dang, M. (2016). Multidimensional aspects of parental Involvement in Korean adolescents' schooling: A mediating role of general and domain specific self-efficacy. Educational Psychology, 36, 916-934.

Zakaria Abd R., Hasim, Z., Salleh Umi K., \& Yusoff Jal, Z. (2013). Family context and its relationship with parental involvement in the education of secondary school children. International Journal of Asian Social Science, 3(4), 1063-1076. 